\title{
Geostatistical techniques applied to spatial distribution of macroorganisms in soybean crop
}

\author{
Lenon Henrique Lovera ${ }^{1}$, Elizeu De Souza Lima ${ }^{1}$, Rafael Montanari ${ }^{2}$, Zigomar Menezes de Souza ${ }^{1}$, Camila \\ Viana Vieira Farhate ${ }^{1}$, Milton Cesar Costa Campos ${ }^{3}$, José Luiz Rodrigues Torres ${ }^{4 *}$
}

${ }^{1}$ State University of Campinas (Unicamp), School of Agricultural Engineering (Feagri), Av. Cândido Rondon, 501 Barão Geraldo 13083-875 - Campinas, São Paulo, Brasil

${ }^{2}$ São Paulo State University (Unesp), Department of Phytosanity, Rural Engineering and Soil, Monção St., 830, 15385-000, Ilha Solteira, São Paulo, Brazil

${ }^{3}$ Federal University of Amazonas, Institute of Education, Agriculture and Environment - Rua 29 de Agosto, 786, Bairro Divino Pranto, 69800-000 - Humaita, Amazonas, Brasil

${ }^{4}$ Federal Institute of Triângulo Mineiro Campus Uberaba, Rua João Batista Ribeiro, 4000, CEP 39064-790 - Uberaba, Minas Gerais, Brasil

\section{*Corresponding author: jlrtorres@iftm.edu.br}

\begin{abstract}
The use of geostatistical techniques has allowed the monitoring of macrofauna spatial variability in crops of economic interest, enabling the creation of maps and more adequate management strategies. The aim of this study is to analyze the spatial dependence of the macrofauna and correlate it to the soybean crop yield along an agricultural year regarding a Hapludox loamy soil with an even slope of $0.025 \mathrm{~m} \mathrm{~m}^{-1}$. The determination of the sampling points of the macrofauna as well as the soybean yield was carried out through a geostatistical mesh. During the soybean growth, we carried out four applications of insecticides for pest control. In the end of the cycle, the soybean grain yield was determined in an area of $3.24 \mathrm{~m}^{2}$ located around the sampling point. Macrofauna collecting was carried out by using a solution of acetylsalicylic acid diluted in water inside a plastic container. The analysis of the spatial dependence was performed by calculating its semivariogram, based on the stationarity assumptions of the intrinsic hypothesis. Organisms in the taxonomic group Hymenoptera (groups of insects that comprise wasps, bees and ants) were the most frequent at the experimental area. Only soy grain yield and the Coleoptera class presented spatial dependence (when the associated variable resembles more the value of the samples in the vicinity than the rest of the locations of the sample set). Coleoptera showed higher spatial concentration in regions of highest soybean yields.
\end{abstract}

Keywords: Grains yield, insects, pests, spatial variability, statistical techniques.

Abbreviations: PG_productivity of soybean grains, Anne_annelid, Ortho_orthoptera, Hyme_hymenoptera, Blatto_blattodea, Gastro_gastropoda, Lepi_lepidoptera, Coleo_coleoptera, Hemi_hemiptera, Dip_Diptera, FD_frequency distribution, Min_ minimum; Max_Maximum, SD_standard deviation, V\%_variation, Kurt_kurtosis; Skew_skewness, gaus_Gaussian, pne_pure nugget effect, SSR_sum of squared residual, SDE_spatial dependence evaluator, MD_Medium dependence, VHD_very high dependence.

Introduction

The cultivation of soybeans is an ever-growing activity in Brazilian agribusiness both regarding production volume and farmed area, having reached the status of one of the most important national commodities (Riffel et al., 2012) due to its high demand in both domestic and foreign market (Espíndola and Cunha, 2015). In the scope of such a large market of soybean demand and supply, Brazil had 33.23 million hectares of cultivated area in harvest year 2015/2016, reaching a production of approximately 102 million tons, with an average yield of $3,073 \mathrm{~kg}$ per hectare (Conab, 2016). However high these figures seem, soybean yield in the country is still limited by abiotic and biotic factors, which are in permanent systemic linkage (Riffel et al., 2012). Soil macrofauna - which includes mites, termites, springtails, earthworms and organisms alike - features organisms which have over $10 \mathrm{~mm}$ in length or over $2 \mathrm{~mm}$ in body diameter, being able to generate direct benefit or harm to the soil and plants (Baretta, 2007). According to Silva et al. (2006), these organisms are one of the soil ecosystem protagonists for occupying several trophic levels within the food chain and affecting primary production both directly and indirectly. Considering the current expansion of cultivated areas along with technological shifts, precision agriculture increases its relevance and consequently soil and production factors are no longer treated as homogeneous; in addition, their spatial variability has been regarded relevant (Mestas et al., 2010). The goal of precision agricultures are both the exploration and monitoring of the productive characteristics in search of the best management strategy to rationalize the use of inputs (Resende et al., 2014), which can increase crop yield potential (Park et al., 2011). Several techniques have been used to determine spatial variations of the soil macrofauna, including geostatistics as one of the most frequently used. This 
method predicates that the difference in the value of a given variable (Blackshaw and Vernon, 2006) depends on the distance between at least two points and its use is associated with techniques adopted to analyze and infer values of a variable distributed in space or time (Farias et al., 2008). According to Dal Prá et al. (2011), when insect-pests reach population levels which cause economic damage to the crop, an important aspect to be considered for the application of control measures is the determination of the organisms' spatial distribution; therefore, deciding on the technique and sampling mesh is a fundamental factor towards interfering on the efficiency of the aforementioned control method. Geostatistical analysis has been widely used for pest control in agriculture; Farias et al. (2004) used geostatistics to determine the spatial distribution of leafhoppers, Xylella fastidiosa vector in citrus. Castrignanò et al. (2012) studied the temporal and spatial population dynamics as well as the delimitation of an entire area of Oleae bactrocera using geostatistics. Lasmar et al. (2012) also employed the same method to determine the spatial distribution and rate of leaf-cutter ants' infestation (Hymenoptera: Formicidae) in eucalyptus plantation. Finally, Duarte et al. (2015) studied the spatial distribution of Grapholita molesta (Busck) (Lepidoptera: Tortricidae) on peach fields. All these authors were able to model the semivariogram for the preparation of kriging maps by showing the areas with higher macrofauna infestation.

Therefore, the use of geostatistical techniques enables the monitoring of the spatial variability of the macrofauna in crops of economic interest, allowing the creation of maps and more adequate management strategies to determine the potential of the cultures to be hosts of pest-insects, generating important information to be used in an integrated pest management program (Park et al., 2011). However, the literature still lacks studies on a spatial distribution of macroorganisms in soy crop.

In this context, our aim is to analyze the spatial dependence of the macrofauna and correlate it to the yield of soybean crop by using geostatistical techniques.

\section{Results and discussions}

\section{The productivity of soybeans}

The analysis of the values of soybean grains productivity (PG) revealed high variability with a coefficient of variation (CV) of $39 \%$ (Table 1). This variation of soybean productivity is related to the incidence of macrofauna found in the area of study, influenced by the level of infestation of orthoptera, hemiptera and gastropods (Sosa-Gómez et al., 2014), hymenopteras (Moreira e Aragão, 2009), lepidoptera and coleoptera (Hoffmann-Campo et al., 2012), at the phenological stage of the crop (Hoffmann-Campo et al., 2000).

In addition, the macrofauna was collected at its reproductive phase, a period with the occurrence of nutrient displacement of the leaves for the formation of pods and grains, consequently generating greater effect in the production in comparison with other stages of plant development (Degrande and Vivian, 2007).

The coefficient of variation (CV) is used as a parameter to validate the mean values found considering that values higher than $20 \%$ are not very significant and above $30 \%$ the values reflect a very heterogeneous data series, nullifying the reliability of the average (Pimentel-Gomes and Garcia, 2002). The CV results indicate that the use of mean values is not an adequate characterization of the variability of soybean and macrofauna productivity as its high variability is statistically likely to result in productivity overestimation or underestimation. Thus, in this case, the mean value should be used to represent the respective data.

\section{The insect classes assessed}

\section{Hymenoptera}

We observed a higher occurrence of this taxonomic group at the experimental area regarding Hymenoptera organisms, including wasps, bees and ants encompassing $33 \%$ of the total organisms found (Table 1). The high density of ants in the cultivated systems is not necessarily a negative indication. It is quite the opposite as it denotes a more complex and favorable community environment for its highquality food. This wide occurrence associated with the variety of feeding habits provides these organisms with the potential to act as efficient pollinators, seed dispersers, detritivores and predators with active participation in the dynamic balance of agroecosystems (Lobry de Bruyn, 1999; Silva, et al, 2006).

Rodrigues, (2009) worked with sugarcane crop in an area of Nitossolo Vermelho Eutroférrico, according to Embrapa (2013) (according to the Soil Taxonomy - USA is a Ultisols) and obtained the largest amount of individuals of the order Hymenoptera; in this case, the group was influenced by straw and soil moisture conditions. According to Rovedder et al. (2008), the order Hymenoptera is one of the most important groups in tropical and subtropical soil due to the abundance of organisms, depending on soil aspects, including pedologic and ecological balance.

\section{Dermaptera and Lepidoptera}

Probably due to four applications of pesticides in the area, the dermaptera and lepidoptera classes occurred less frequently, (Table 1). In a study on the control of caterpillars in soybean cultivation with localized application, Aita et al. (2015) verified an efficient control level; at the sites which received the spraying, a progressive decrease in the number of caterpillars occurred in relation to the sites without the application of insecticide. The same authors pointed out that insecticide applications can be carried out in places where the population surpasses the control level leading to a reduction in the absolute application of insecticides in relation to the control area.

\section{Anelida, Orthoptera, Blattodea, Gastropoda, Coleoptera, Hemiptera and Araneae}

According to Batista et al. (2014), the macrofauna present in the soil is an attribute sensitive to the impact of the different production systems. These individuals belonging to the studied orders develop diverse functions as predators of soybean pests, decomposers and mutualism with the local microfauna in addition to participating in soil aspects, influencing the soil aggregation process and consequently altering soil porosity. 
Table 1. Initial descriptive analysis of productivity and macrofauna in soybean crop at an experimental area.

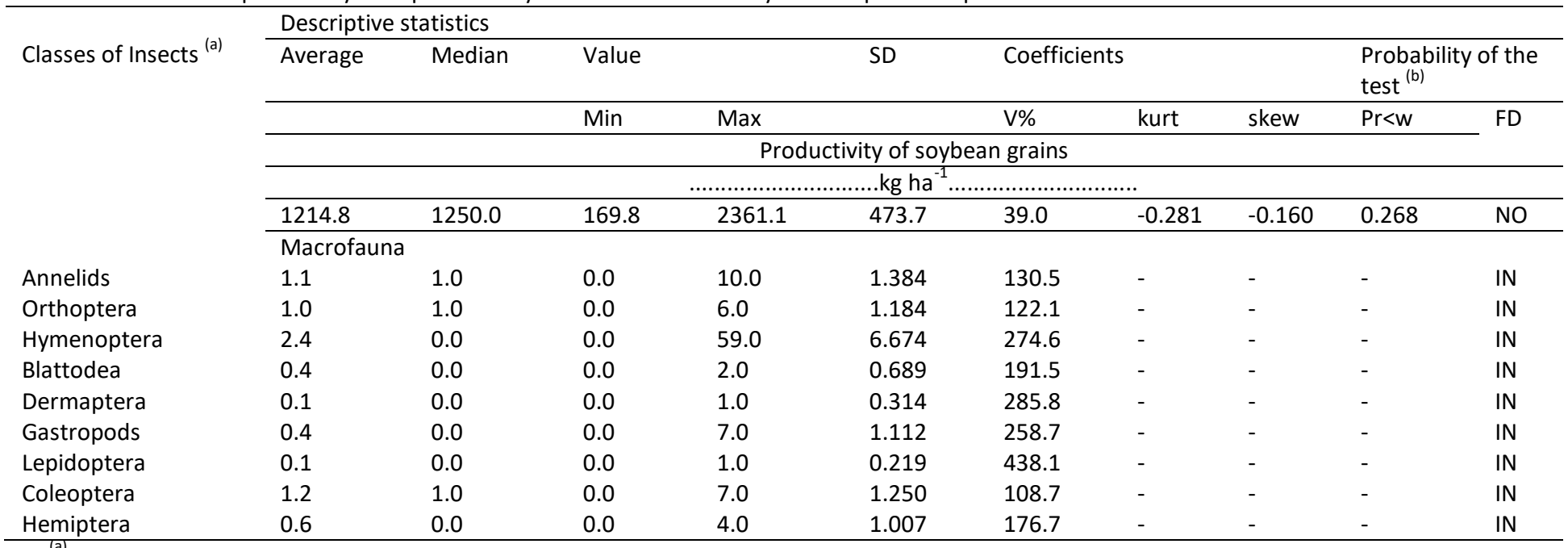

${ }^{(a)}$ FD = frequency distribution, being NO and IN respectively of the normal and indeterminate type; Min = minimum; Max = Maximum; SD = standard deviation; V\% = variation; kurt = kurtosis; Skew = skewness.

Table 2. Parameters of simple semivariograms adjusted for productivity and macrofauna in soybean crop at the experimental area.

\begin{tabular}{|c|c|c|c|c|c|c|c|c|}
\hline \multirow{6}{*}{$\begin{array}{l}\text { Classes of } \\
\text { insects }^{\text {(a) }}\end{array}$} & \multicolumn{8}{|c|}{ Parameters } \\
\hline & Model $^{(b)}$ & Nugget effect & & Range & $r^{2}$ & $\operatorname{SSR}^{(c)}$ & $\mathrm{SDE}^{(\mathrm{d})}$ & \\
\hline & & $\left(C_{0}\right)$ & $\left(C_{0}+C\right)$ & $\left(A_{0}\right)(m)$ & & & $\%$ & Class \\
\hline & \multicolumn{8}{|c|}{$\gamma(h)$ simple attributes of the plant } \\
\hline & \multicolumn{8}{|c|}{ PG } \\
\hline & esf (233) & $9.890 \times 10^{1}$ & $2.330 \times 10^{2}$ & 28.3 & 0.829 & $1.240 \times 10^{9}$ & 57.6 & MD \\
\hline & \multicolumn{8}{|c|}{$\gamma(h)$ simple attributes biological } \\
\hline Annelids & pne & 1.370 & 1.370 & - & - & - & - & - \\
\hline Orthoptera & pne & 1.346 & 1.346 & - & - & - & - & - \\
\hline Hymenoptera & pne & $4.512 \times 10^{1}$ & $4.512 \times 10^{1}$ & - & - & - & - & - \\
\hline Blattodea & pne & $1.338 \times 10^{1}$ & $1.338 \times 10^{1}$ & - & - & - & - & - \\
\hline Dermaptera & pne & $1.033 \times 10^{-1}$ & $1.033 \times 10^{-1}$ & - & - & - & - & - \\
\hline Gastropods & pne & 1.324 & 1.324 & - & - & - & - & - \\
\hline Lepidoptera & pne & $4.336 \times 10^{-2}$ & $4.336 \times 10^{-2}$ & - & - & - & - & - \\
\hline Coleoptera & gaus (51) & $1.790 \times 10^{-1}$ & 1.455 & 7.6 & 0.498 & $1.820 \times 10^{-1}$ & 87.7 & VHD \\
\hline Hemiptera & pne & $9.614 \times 10^{-1}$ & $9.614 \times 10^{-1}$ & - & - & - & - & - \\
\hline
\end{tabular}

${ }^{(a)}$ Anne = annelid; Ortho = orthoptera; Hyme = hymenoptera; Blatto = blattodea; Gastro = gastrópoda; Lepi = lepidóptera; Coleo = coleóptera; Hemi = hemíptera; Dip = Diptera. ${ }^{(b)}$ sph = spherial, gaus = gaussian; pne = pure nugget effect; model succeeded by number in parentheses, meaning the number of pairs in the first lag; ${ }^{\left({ }^{c}\right)}$ SSR = sum of squared residual; ${ }^{\left({ }^{d}\right)} \mathrm{SDE}=$ spatial dependence evaluator, and MD = Medium dependence and VHD = very high dependence.

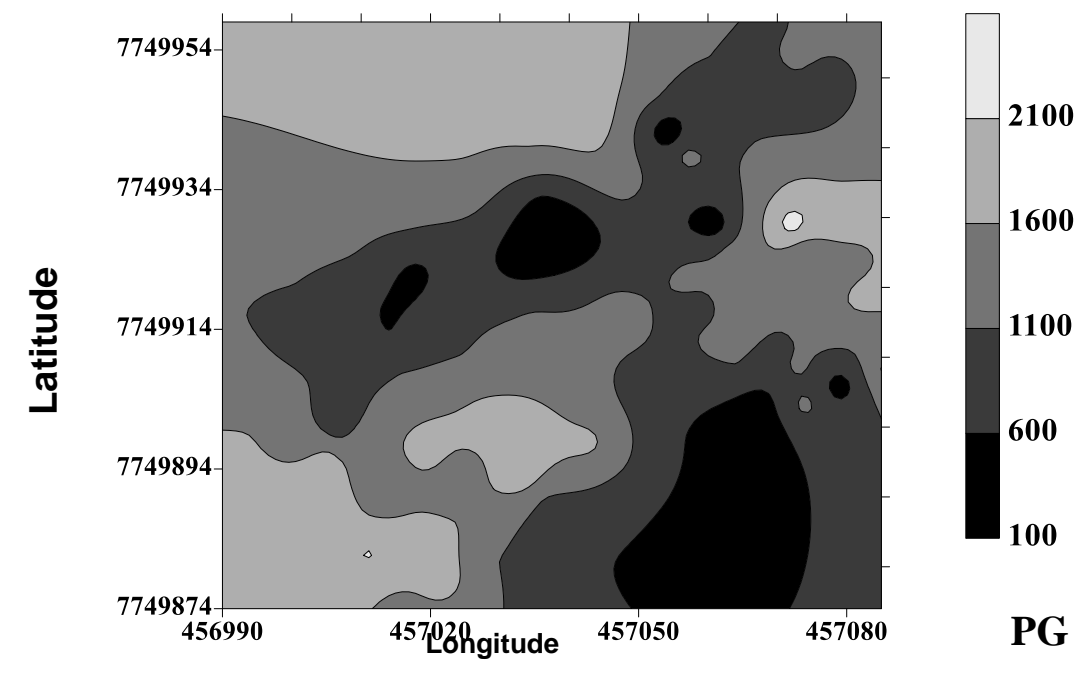

Fig 1. Spatial distribution of productivity of soybean grains (PG) in experimental area. 


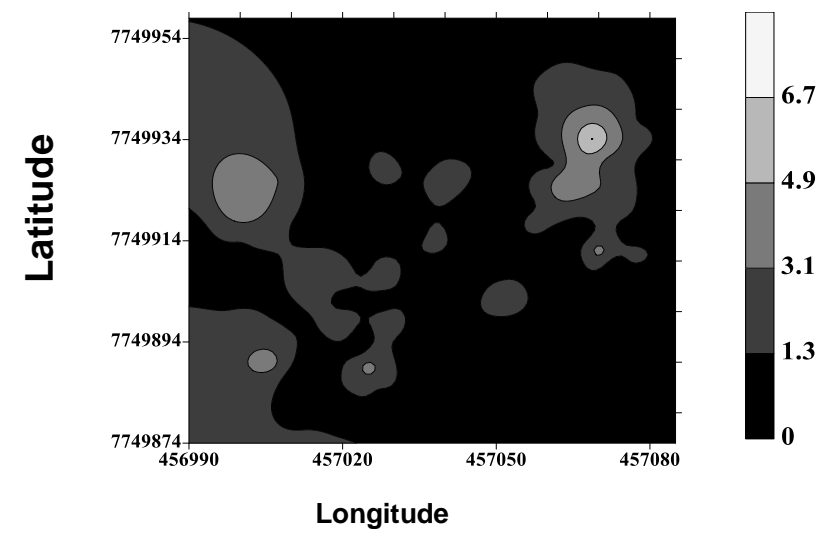

Coleo

Fig 2. Spatial distribution maps of the Coleoptera (Coleo) class in soybean crop.
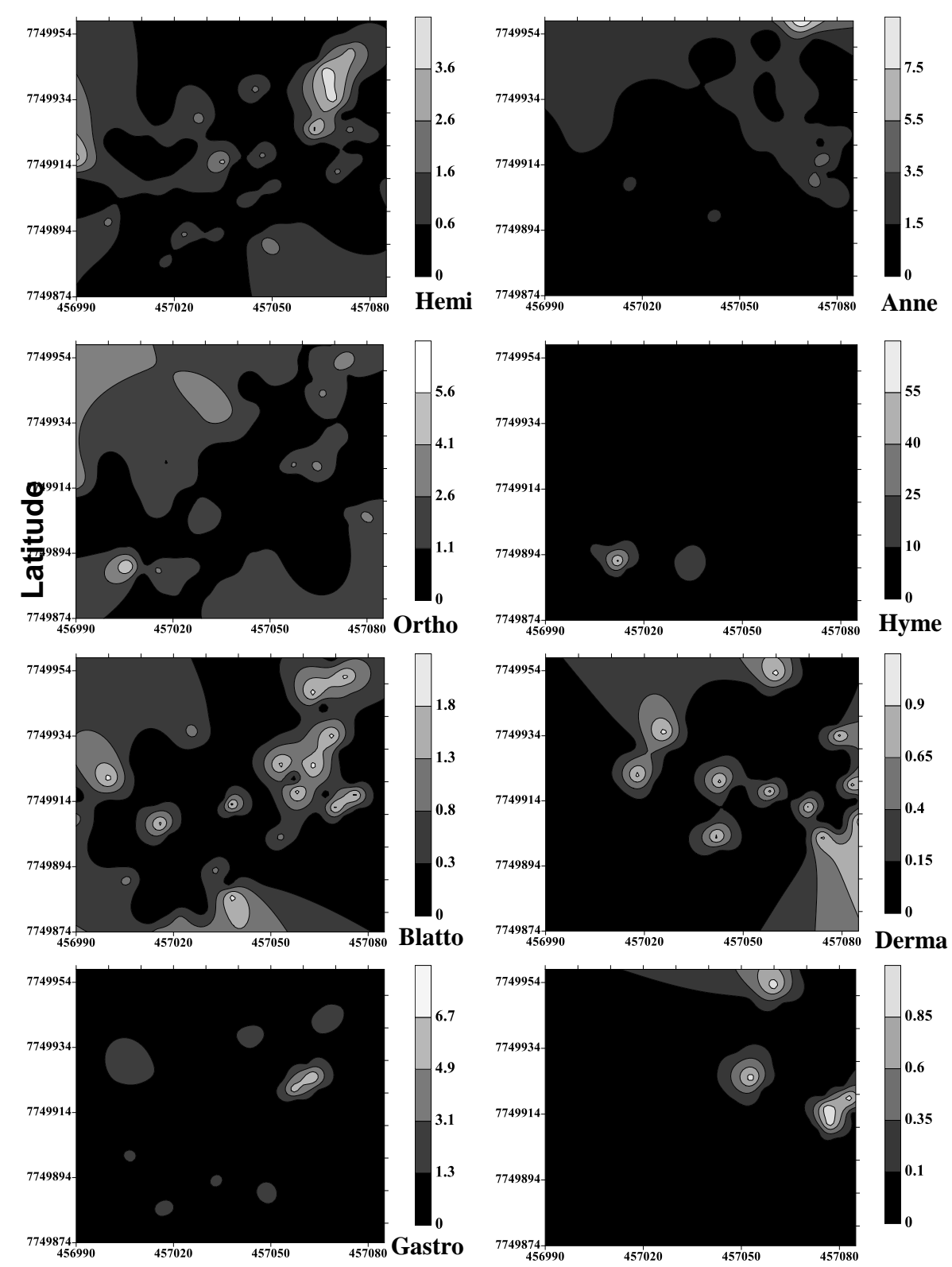

Fig 3. Spatial distribution maps of the insect class in soybean crop. 
All insect classes showed very high variability, with CV between 108.7 and 438.1\% (Table 1). Dinardo-Miranda et al. (2007) studied Mahanarva fimbriolata in sugarcane and Pazini et al. (2015) analyzed the spatial distribution of Tibraca limbativentris in flooded rice in Planalto da Campanha, Rio Grande do Sul, Brazil, and found very high CVs, above 47 and $121 \%$, respectively. These results showed that high CVs values occurred because the macrofauna had not present stationarity; therefore, these insects show ability to move consequently providing great variability regarding the amount of individuals at the sampling sites for the total experimental area.

None of the macrofauna insect classes presented data normality - which might compromise kriging estimates due to longer graph tails; however, it does not hamper geostatistical analysis (Isaaks and Srivastava, 1989). According to Souza et al. (2004), more important than the normality of the data is the occurrence or not of the proportional effect in which the mean and the variance of the data are not constant in the study area.

In order to determine the spatial variability of the data, the samples were subjected to a geostatistical analysis using semivariographic models to achieve the best adjustment, that is, with higher determination coefficient, minimal sum of the squares of residual values, and greater evaluators of spatial dependence degree (Vieira, 2000). The spatial variability of macrofauna (Table 2 ) is influenced by physical factors, which means not all points in space are equally likely to be occupied; in addition, biological factors occur where survival-threatening conditions are more favorable than in others spots (Dias et al., 2012).

\section{The degree of spatial dependence}

The proposed interpretation for the degree of spatial dependence (ADE) (Dalchiavon et al., 2012) is presented as follows: a) $A D E \angle 20 \%=$ spatial variable of very low dependence; b) $20 \% \leq \mathrm{ADE}<40 \%=$ low dependence; c) $40 \%$ $\leq \mathrm{ADE}<60 \%$ = medium dependence; d) $60 \% \leq \mathrm{ADE}<80 \%=$ high dependence; e) $80 \% \leq \mathrm{ADE}<100 \%=$ very high dependence. Only the spatial dependence found occurred between the soybean PG and the Coleoptera, regarded as mean and very high (Table 2), respectively, showing that the highest populational concentration of the Coleoptera class was distributed in an aggregate manner throughout the area. These results corroborate Stecca (2011) regarding the report of having achieved a spatial dependence verified only upon an increase in the population density of the insect class.

Coleoptera presented the lowest value in the range, indicating that the points sampled were similar at a radius of $7.6 \mathrm{~m}$; for soybean PG, in turn, the radius was $28.3 \mathrm{~m}$ (Table 2). This parameter was provided through the geostatistical analysis and is fundamentally important for representing the distance within which a regionalized variable presents spatial continuity, which means that beyond this distance, the spatial behavior of the variable becomes totally random (Lemos Filho et al., 2008). However, regarding the semivariogram, these range values are essential to verify the spatial dependence, which is recommended to manage the use of spacing values below the range found (Pazini et al., 2015).
The kriging map of productivity of soybean grains (PG) reveals that the highest value $\left(1.394 \mathrm{~kg} \mathrm{ha}^{-1}\right)$ occurs in the southwest, north, part of the south, northeast and east (Figure 1); as for the remaining regions, productivity varied between $972-550 \mathrm{~kg} \mathrm{ha}^{-1}$.

All of the macrofauna kriging maps, except Coleoptera (Figure 2), were carried out by using Surfer 8.0 software because of their pure nugget effect in order to present the spatial distribution of all macrofauna collected during the experiment. We observed that the distribution occurred in an aggregate manner presenting the highest productivity values where the largest infestation of Orthoptera, Blattodea, Gastropoda, Coleoptera and Hemiptera occurred (Figure 3).

The Coleoptera kriging map presented spatial dependence and demonstrated that the highest concentration occurred in the northwestern, southwestern and western regions (Figure 2), where the highest soybean yields also occurred. A possible explanation is the fundamental role played by the Coleoptera in agricultural areas regarding the decomposition of feces left by other insects, as well as benefiting from the decomposition of the soil organic matter, which favors the recycling of nutrients and availability of these plants (Monção et al., 2011).

Acknowledging the space-time dynamics of Coleoptera as a function of soybean productivity is important for the development of crop management strategies; therefore, the information obtained (Dal Prá et al., 2011) from the kriging maps regarding the occurrence and distribution of Coleoptera in the study area allows the use of precision farming tools through the georeferencing of Coleoptera in the soybean crop as well as enables the development of management strategies aimed to increase soybean production without causing environmental impacts (Riffel et al., 2012).

\section{Materials and methods}

\section{History of the area and planted variety}

This area had substituted corn or soybean (summer) crops with beans or maize (winter) for 28 years. Over the first 15 years, conventional tillage was carried out for the cultivation of the abovementioned crops; along the past 13 years, notillage was used. In agricultural year of 2013/14 began the experiment with the planting of soybean (variety Valiosa $R R)$.

\section{Location of the experimental area}

The study was conducted at the experimental area of the Teaching, Research and Extension Farm, Plant Production Sector, School of Engineering of Ilha Solteira (FTRE/UNESP), located in Selvíria, Mato Grosso do Sul, Brazil, between latitude $20^{\circ} 22^{\prime} \mathrm{S}$ and longitude $51^{\circ} 22^{\prime} \mathrm{W}$, at an altitude of 345 meters.

\section{Metrologicaland wheater information}

Weather in the region was classified as Aw according to the Köeppen classification, thus characterized as humid tropical with a rainy season in the summer and a dry season in the 
winter. The mean annual precipitation and temperature in the region is $1300 \mathrm{~mm}$ and $23.7^{\circ} \mathrm{C}$, respectively.

\section{Soil characterization}

The soil of the area was classified as Latossolo Vermelho distroférrico típico according to classification by Embrapa, (2013) and Hapludox Typic according to a soil taxonomy system (Soil Survey Staff, 2014) with clayey texture and a homogeneous slope of $0.025 \mathrm{~m} \mathrm{~m}^{-1}$, included as one of the classes of greater occurrence in Brazil.

\section{The sampling points}

Macrofauna sampling sites and soybean grains productivity were determined through a geostatistical mesh which was implanted in the area with soybean cultivation by using a common optical level, where a sample mesh was installed containing 100 points distributed to cover the entire experimental area $\left(7,980 \mathrm{~m}^{2}\right)$.

During soybean plant growth, four applications of insecticides for pest control were carried out: first at day 30 , second at day 50 , only for caterpillar control, and the last two at days 75 and 95 for the control of caterpillars and bedbugs. We used the systemic acaricide insecticide with active principle Acephate at a dosage of $0.830 \mathrm{~g} \mathrm{ha}^{-1}$ to control caterpillars; for bugs control, we applied a systemic insecticide with active principle Imidaclopride and BetaCiflutrina at a dosage of $0.750 \mathrm{~g} \mathrm{ha}^{-1}$.

Macrofauna collection took place on January, $30^{\text {th }}, 2014$. Open-top round plastic vessels were placed in holes made on the ground where they fit both in height and in diameter, leveling their top with the soil. Inside them it was poured $200 \mathrm{~mL}$ of water in which was diluted acetylsalicylic acid. Over the open top the vessel, wood sticks longer than the vessel diameter were laid and upon them was finally placed a plastic lid. This top cover is very important to prevent the liquid from diluting more and overflowing with rainwater as well as to prevent leaves or twigs from crossing the trap which would hinder the capture of the insects.

After a week, the vessels were taken to the laboratory and the samples were sorted manually; the organisms found had over $10 \mathrm{~mm}$ in length or a body diameter larger than $2 \mathrm{~mm}$ and were subsequently counted and identified according to their taxonomic groups.

\section{Determination of soybean productivity}

The productivity of soybean was determined by analyzing an area of $3.24 \mathrm{~m}^{2}$, within which there were four $1.80 \mathrm{~m}$-long soybean plant lines, with a distance of $0.45 \mathrm{~m}$ from each other. The harvest of the soybean crop consisted of pulling out the previously identified plants at day 130 after the sowing (March, $25^{\text {th }}, 2014$ ). The material of each sampling site was sun-dried with subsequent execution of the trail using a trail-machine, which separated the soybean grains from the straw of the plant. The values of PG were corrected to $13 \%$ moisture and extrapolated in $\mathrm{kg} \mathrm{ha}^{-1}$.

For the macrofauna and PG of the soybean studied, the descriptive analysis was developed using SAS software (Schlotzhaver and Littell, 1997) by calculating the mean, median, mode, minimum and maximum values, as well as standard deviation, coefficient of variation, kurtosis, and asymmetry. Afterwards, the anomalous points (outliers) were identified in the chart of branches and leaves, replacing them with the mean value of the surrounding amounts in the geostatistical meshwork. The frequency distribution of the data was also analyzed. Thus, Shapiro and Wilk test at $5 \%$ was used to test the normality hypothesis, in which the $\mathrm{W}$ test checks the null hypothesis, which, in turn, evaluates whether the sample comes from a population with normal distribution or not.

\section{Geostatistical analysis of data}

The spatial dependence was measured by calculating the semivariogram based on the assumptions of the stationarity of the intrinsic hypothesis, using the geostatistical software Gamma Design (GS +, 2004). Simple semivariograms were adjusted for macrofauna and soybean PG. The adjustments of the mathematical models to the experimental semivariograms were conducted primarily through the initial selection of: a) the highest coefficient of determination $\left(r^{2}\right)$; b) the lowest sum of the squares of the deviations (SSD), and c) the largest evaluator of the degree of spatial dependence (DED).

The final decision on the model to represent the adjustment was made using cross validation, which also occurred for the definition of the size of the neighborhood that provided the best kriging mesh, performed through block kriging. For each attribute, it was estimated the nugget effect $(\mathrm{Co})$, the range $(\mathrm{Ao})$ and the plateau $(\mathrm{Co}+\mathrm{C})$. Surfer 8.0 software was used to elaborate the maps of krigagens.

\section{Conclusion}

The organisms belonging to the taxonomic group Hymenopteras presented greatest occurrence at the experimental area. The productivity of soybean grains and Coleoptera class distribution showed spatial dependence, having a greatest concentration in regions where also the greatest productivities occur. For the hemiptera and blattodea classes, which showed pure nugget effect, the highest concentrations were determined in areas of highest productivity.

\section{Acknowledgments}

The authors would like to thank the Foundation for the development of UNESP-FUNDUNESP (process number 0235/001/14-PROPe/CDC) for funding the project and Technological Development (CNPq) for granting our scholarship.

\section{References}

Aita V, Magano DA, Machado MRR, Guedes JVC (2015) Manejo de lagartas na cultura da soja com aplicação de controle localizado. Interc. 40: 784-788.

Baretta D (2007) Fauna do solo e outros atributos edáficos como indicadores da qualidade ambiental em áreas com Araucaria angustifolla no estado de São Paulo. 159 f. Tese (Doutorado) - Escola Superior de Agricultura Luiz de Queiroz, Piracicaba. 
Batista I, Correia MEF, Pereira MG, Bieluczyk W, Schiavo, JÁ, Rouws JRC (2014) Frações oxidáveis do carbono orgânico total e macrofauna edáfica em sistema de integração lavoura-pecuária. R. Bras. Ci. Solo, 38: 797-809.

Blackshaw RP, Vernon RS (2006) Spatio temporal stability of two beetle populations in non-farmed habitats in an agricultural landscape. Jour of Appl Ecol. 43: 680-689.

Castrignanò A, Boccaccio L, Cohen Y, Nestel D, Kounatidis I, Papadopoulos NT, Benedetto D, Mavragani-Tsipidou $P$ (2012) Spatio-temporal population dynamics and areawide delineation of Bactrocera oleae monitoring zones using multi-variate geostatistics. Prec Agric. 13: 421-441.

CONAB - Companhia Nacional de Abastecimento . Acompanhamento da safra brasileira: grãos, v. 3 - Safra 2015/16, n. 8 - Quarto levantamento, Brasília, p.1-154, janeiro 2016.

Dal Prá E, Guedes JVC, Cherman MA, Jung AH, Silva SJP, Ribas GG (2011) Uso da geoestatística para caracterização da distribuição espacial de larvas de Diloboderus abderus. Ci Rur. 41: 1689-1694.

Dalchiavon FC, Carvalho MP, Andreotti M, Montanari R (2012) Variabilidade espacial de atributos da fertilidade de um Latossolo Vermelho Distroférrico sob Sistema Plantio Direto. Rev Ci Agr. 43: 453-461.

Degrande PE, Vivian LM (2007) Pragas da Soja. In: Boletim de Pesquisa da Soja: Fundação MT, 274p.

Dias NP, Medeiros LR, Pazini JB, Silva FF (2012) Distribuição espacial de Procornitermes sp. (Isoptera: Termitidae) em função das propriedades físicas do solo em área de pastagem no município de São Borja, Rio Grande do Sul. Rev Br Agroec. 7: 104-111.

Dinardo-Miranda LL, Vasconcelos ACM, Vieira SR, Fracasso JV, Grego CR (2007) Uso da geoestatística na avaliação da distribuição espacial de Mahanarva Fimbriolata em canade-açúcar. Brag. 66: 449-455.

Duarte F, Calvo MV, Borges A, Scatoni IB (2015) Geostatistics and Geographic Information Systems to Study the Spatial Distribution of Grapholita molesta (Busck) (Lepidoptera: Tortricidae) in Peach Fields. Neot Entom. 44: 319-327.

Embrapa - Empresa Brasileira de Pesquisa Agropecuária. Sistema brasileiro de classificação de solos. 3a ed. Brasília, EMBRAPA, 2013, 353p.

Espíndola CJ, Cunha RCC (2015) A dinâmica geoeconômica recente da cadeia produtiva da soja no Brasil e no mundo. GeoT. 11: 217-238.

Farias PRS, Barbosa JC, Busoli AC, Overal WL, Miranda VS, Ribeiro SM (2008) Spatial analysis of the distribution of Spodoptera frugiperda (Lepidoptera: Noctuidae) and losses in maize crop productivity using geostatistics. Neot Entom. 37: 321-327.

Farias PRS, Roberto SR, Lopes JRS, Perecin D (2004) Geostatistical characterization of the spatial distribution of Xylella fastidiosa sharpshooter vectors on citrus. Neot. Ent, 33: 13-20.

Gamma Design Software : $\mathrm{GS}^{+}$. (2004) Geostatistics for Environmental Sciences. 7th.ed. Michigan, Plainwell: Gamma Desing Software.

Hoffmann-Campo CB, Mosxardi F, Corrêa-Ferreira B, Oliveira L, Sosa-Gómez DR, Panizzi AR, Corso IC, Gazzoni DL, Oliveira EB (2000) Pragas da soja no brasil e seu manejo integrado. Londrina: Embrapa Soja, 70p. (Circular técnica, 30)
Hoffmann-Campo CB, Oliveira L, Moscardi F, Corrêa-Ferreira BS, Corso IC (2012) Pragas que Atacam Plântulas, Hastes e Pecíolos da soja. In: Hoffmann-Campo, C. B.; CorrêaFerreira, B. S.; Moscardi, F. Soja: Manejo Integrado de Insetos e outros Artrópodes-praga. Brasília: Embrapa, p.145-212.

Isaaks EH, Srivastava RM (1989) An introduction to applied geoestatistics. New York: Oxford University, 561p.

Lasmar O, Zanetti R, Santos A, Fernandes BV (2012) Use of Geostatistics to Determine the Spatial Distribution and Infestation Rate of Leaf-Cutting Ant Nests (Hymenoptera: Formicidae) in Eucalyptus Plantations. Neot Entom. 41: 324-332.

Lemos Filho LCA, Oliveira EL, Faria MA, Andrade LAB (2008) Variação espacial da densidade do solo e matéria orgânica em área cultivada com cana-de-açúcar (Saccharum officinarum L.). Rev Ci Agr. 39: 193-202.

Lobry de Bruyn LA (1999) Ants as bioindicators of soil function in rural environments. Agr Ecos and Envir. 74: 425-441.

Mestas RM, Roque MW, Matsura EE, Bizary DR, Paz A (2010) Variabilidad espacial de los atributos físico-hídricos del suelo y de la productivi-dad del cultivo de fréjol (Phaseolus vulgaris $\mathrm{L}$ ) irrigado bajo un sistema de siembra directa. Rev Ci Agr. 33: 307-313.

Monção OP, Quadros DG, Oliveira DNS, Almeida RG, Bezerra ARG, Mauricio IS (2011) Importância agronômica de coleópteros coprófagos. Enc Bio. 7: 1-8.

Moreira HJC, Aragão FD (2009) Manual De Pragas Da Soja. Campinas, $144 p$.

Park JJ, Lee JH, Shin KI, Lee SE, Cho K (2011) Geostatistical analysis of the attractive distance of two different sizes of yellow sticky traps for greenhouse whitefly, Trialeurodes vaporariorum (Westwood) (Homoptera: Aleyrodidae), in cherry tomato greenhouses. Aust Jou Ent. 50: 144-151.

Pazini JB, Botta RA, Seide EJ, Silva FF, Martins JFS, Barrigossi JAF, Rübenich R (2015) Geoestatística aplicada ao estudo da distribuição espacial de Tibraca limbativentris em arrozal irrigado por inundação. Ci Rur. 45: 1006-1012.

Pimentel-Gomes F, Garcia CH (2002) Estatística aplicada a experimentos agronômicos e florestais: exposição com exemplos e orientações para uso de aplicativos. Piracicaba: Fundação Escola de Agricultura Luiz de Queiroz, 309p.

Resende Av, Hurtado Smc, Vilela Mf, Corazza Ej, Shiratsuchi Ls (2014) Aplicações da agricultura de precisão em sistemas de produção de grãos no Brasil. In: Bernardi Acc, Naime Jm, Resende Av, Bassoi Lh, Inamasu Ry (2014) Agricultura de precisão: resultados de um novo olhar. Brasília: Ed. Embrapa, cap. 2, p. 192-339.

Riffel CT, Garcia MS, Santi AL, Basso CJ, Flora LPD, Cherubin MR, Eitelwein MT (2012) Densidade amostral aplicada ao monitoramento georreferenciado de lagartas desfolhadoras na cultura da soja. Ci Rur. 42: 2112-2119.

Rodrigues (2014) Variabilidade especial de Atributos físicos, químicos e biológicos do solo e a produtvidade da cana-deaçúcar (Doutorado em Agricultura Tropical e Subtropical) Instituto Agronômico, Campinas.

Rovedder APM, Eltz FLF, Dreacher MS, Schenato RB, Antoniolli ZI (2009) Organismos edáficos como bioindicadores da recuperação de solos degradados por arenização no Bioma Pampa. CI Rur. 39: 1061-1068.

Schlotzhaver Sd, Littell Rc (1997) SAS system for elementary statical analysis. 2nd.ed. Cary: SAS. 
Silva RF, Aquino AMA, Mercante FM, Guimarães MF (2006) Macrofauna invertebrada do solo sob diferentes sistemas de produção em Latossolo da Região do Cerrado. Pesq Agr Br. 41: 697-704.

Soil Survey Staff. Keys to soil taxonomy. 2014. 12th ed. Washington, DC: USDA-Natural Resources Conservation Service.

Sosa-Gómez DR, Corrêa-Ferreira BS, Hoffmann-Campo CB, Corso IC, Oliveira LJ, Moscardi F, Panizzi AR, Bueno AF, Hirose E, Roggia S (2014) Manual de identificação de insetos e outros invertebrados da cultura da soja. Londrina: Embrapa Soja. 100p.
Souza ZM, Júnior JM, Pereira GT, Moreira LF (2004) Variabilidade espacial do $\mathrm{pH}, \mathrm{Ca}, \mathrm{Mg}$ e $\mathrm{V} \%$ do solo em diferentes formas do relevo sob cultivo de cana-de-açúcar. Ci Rur. 34: 1763-1771.

Stecca CS (2011) Distribuição espaço-temporal e flutuação populacional de lagartas desfolhadoras de soja. Dissertação de mestrado (Mestrado em Agronomia) Universidade Federal de Santa Maria, Santa Maria.

Vieira SR (2000) Geoestatística em estudos de variabilidade espacial do solo. In: Novais RF, Alvarez VH, Schaefer CEGR (Eds.) (2000) Tópicos em ciência do solo. Viçosa, MG: Sociedade Brasileira de Ciência do Solo, p. 154. 